\title{
Decreased ventilatory function in hard metal workers
}

\author{
Y Kusaka, M Iki, S Kumagai, S Goto
}

\begin{abstract}
Objectives-To study individual effects on pulmonary function of exposure to hard metal including cobalt.

Methods-All of the workers in a hard metal company (583 men and 120 women) were examined for smoking, respiratory symptoms, ventilatory function, occupational history of exposure to hard metal, and present exposure to airborne cobalt. The ventilatory function indices (forced vital capacity (FVC), forced expiratory volume in one second $\left(\mathrm{FEV}_{1}\right)$, forced expiratory volume in one second per cent $\left(\right.$ FEV $\left._{1} \%\right)$, peak expiratory flow (PEF), mid-maximal flow (MMF), forced expiratory flow at $50 \%$ vital capacity $\left(\dot{V}_{50}\right)$, forced expiratory flow at $25 \%$ vital capacity $\left.\left(\dot{\mathbf{V}}_{25}\right)\right)$ were standardised for height and age and expressed as a percentage of predicted values.
\end{abstract}

Results-Two way analysis of variance of indices of ventilatory function showed that an interaction of hard metal exposure and smoking decreased $\% \dot{V}_{50}$ for both men and women. Among the currently exposed men, those with asthmatic symptoms (defined as reversible dispnoea with wheeze) had significantly lower $\%$ FVC, $\%$ FEV $_{1} \%, \%$ PEF, \%MMF, $\% \dot{V}_{50}$, and $\% \dot{V}_{25}$ than did workers without asthma. The ventilatory disfunction did not differ between exposed and nonexposed workers with asthmatic symptoms. Even among the men without asthmatic symptoms, $\% \dot{V}_{50}$ was significantly lowered by the interaction of hard metal exposure and smoking. The multilinear regression analysis of indices of ventilatory function for all of the subjects on sex, smoking (Brinkman index), exposure to hard metal, and asthmatic symptoms showed that asthmatic symptoms and smoking had significant effects on all variables and that the decrease in $\% \dot{V}_{25}$ was associated with hard metal exposure. In the currently exposed and non-exposed workers, multilinear regression analysis applying indices for cobalt exposure (mean cobalt concentration, duration of exposure, and cumulative dose) showed that not only asthmatic symptoms or smoking but also duration of exposure had significant decreasing effects on $\% F V C, \% M M F$, and $\% \dot{V}_{25}$. Conclusions-Occupational exposure to hard metal probably causes impairment of ventilatory function in a dose dependent manner.

(Occup Environ Med 1996;53:194-199)

Keywords: hard metal; cobalt; pulmonary function

Occupational exposure to hard metal including cobalt is known to cause interstitial pneumonitis, pulmonary fibrosis, and asthma among workers. ${ }^{1-3}$ Cobalt has been suspected of provoking asthma in some people by hypersensitivity ${ }^{4}$ and has also been assumed to be responsible for pneumonitis and pulmonary fibrosis on the basis of the results of animal experiments. ${ }^{56}$ As well as case reports on these disorders, the ventilatory function of hard metal workers has also been reported with special reference to the concentrations of airborne cobalt in Swedish, ${ }^{7}$ American, ${ }^{8}$ French, ${ }^{9}$ and Japanese ${ }^{10}$ working environments. A field survey was also completed at a Finnish cobalt production plant as early as 1980, in which exposure to cobalt was found to cause asthma and bronchial irritation with increased bronchial reactivity. ${ }^{11}$ There are also recent reports on the relation between level of cobalt exposure and pulmonary function in a cobalt refining industry, ${ }^{12}$ a diamond-cobalt saw producing industry, ${ }^{13}$ and diamond polishing industries $^{14}$ in Belgium. All of these studies showed some decrease in ventilatory function related to cobalt exposure.

The exposure limit for cobalt in many developed countries including Japan has been designated as $50 \mu \mathrm{g} / \mathrm{m}^{3}$. According to the International Labour Office (ILO) statistics ${ }^{15}$, some countries still have a standard for cobalt of $100 \mu \mathrm{g} / \mathrm{m}^{3}$. Adjustment of the exposure limit has been based on reports of the relation between the concentration of airborne cobalt and onset of interstitial pneumonitis or between the concentration of cobalt in the workplace atmosphere and impairment of ventilatory function sometimes associated with respiratory symptoms.

We previously studied an entire group of hard metal workers engaged in shaping presintered hard metal products at a corporation, ${ }^{10}$ and we have continued to accumulate information on the health of hard metal workers at each of the various steps of hard metal production and exposures to airborne cobalt. The data for all the hard metal workers involved in the different manufacturing steps can be subjected to overall analysis of general 
Table 1 Characteristics of subjects

\begin{tabular}{|c|c|c|c|c|c|c|}
\hline Sex & $n(\%)$ & $\begin{array}{l}\text { Age } \\
\text { mean (SD, } \\
\text { range) }\end{array}$ & $\begin{array}{l}\text { Smoking } \\
\text { habit }\end{array}$ & $n(\%)$ & $\begin{array}{l}\text { Exposure to } \\
\text { hard metal } \\
\text { (current cobalt } \\
\text { exposure } \mu \mathrm{g} / \mathrm{m}^{3} \text { ) }\end{array}$ & $n(\%)$ \\
\hline Men & $583(83)$ & $38 \cdot 4(10 \cdot 8,18-69)$ & $\begin{array}{l}\text { Non-smoker } \\
\text { Ex } \\
\text { Current }\end{array}$ & $\begin{array}{r}107(19) \\
92(16) \\
374(65)\end{array}$ & $\begin{array}{l}\text { None } \\
\text { Former } \\
\text { Current } \\
0-50 \\
50-100 \\
>100\end{array}$ & $\begin{array}{r}263(45) \\
75(13) \\
242(42) \\
151(63) \\
37(15) \\
54(22)\end{array}$ \\
\hline Women & $120(17)$ & $34 \cdot 0(11 \cdot 7,18-69)$ & $\begin{array}{l}\text { Non-smoker } \\
\text { Ex } \\
\text { Current }\end{array}$ & $\begin{array}{r}103(87) \\
4(3) \\
12(10)\end{array}$ & $\begin{array}{l}\text { None } \\
\text { Former } \\
\text { Current } \\
0-50 \\
50-100 \\
\text { ND }\end{array}$ & $\begin{aligned} 91(76) \\
1(1) \\
27(23) \\
19(70) \\
3(11) \\
5(19)\end{aligned}$ \\
\hline
\end{tabular}

${ }^{\star} \mathrm{ND}$, not determined.

pulmonary function in relation to concentrations of airborne cobalt.

It is well known that asthma decreases pulmonary function, in some cases with permanent obstructive impairment. Our study ${ }^{3}$ on people with hard metal asthma suggested that continuing exposure to hard metal increases chronic obstructive pulmonary disease. This would indicate that the presence of asthma should be taken into consideration in the analysis of association of cobalt with impairment of pulmonary function.

The purpose of the present study, therefore, was to clarify the relation between the concentrations of airborne cobalt associated with hard metal and the ventilatory function of hard metal workers. Smoking and asthmatic symptoms were also considered as relevant factors in the analysis.

\section{Subjects and methods}

All of the workers (583 men and 120 women) at a hard metal corporation were studied. The factors evaluated included occupational history of exposure to hard metal, respiratory symptoms, smoking, concentrations of airborne cobalt, and ventilatory function. The history of respiratory symptoms was taken by trained interviewers with the Japanese version $^{16}$ of the British Medical Research Council (MRC) questionnaire, ${ }^{17}$ and attacks of reversible dyspnoea with wheeze were defined as asthmatic symptoms. Smoking was determined according to the criteria recommended by the MRC, and the Brinkman smoking index, ${ }^{18}$ multiplication of numbers of cigarettes smoked daily by duration of smoking (years), was calculated. Individual concentrations of airborne cobalt were measured with personal sampling by atomic absorption spec-

Table 2 Two way ANOVA of indices of ventilatory function and exposure to hard metal and smoking in men

\begin{tabular}{lll}
\hline Indices & $\left.\begin{array}{l}\text { Significance } \\
\text { of model }\end{array} R^{2}\right)$ & $\begin{array}{l}\text { Significant } \\
\text { factor }\end{array}$ \\
\hline$\% \mathrm{FVC}$ & No & \\
$\% \mathrm{FEV}$ & & \\
$\% \mathrm{FEV}_{1} \%$ & No & Hard metal exposure $\times$ smoking habit \\
$\% \mathrm{PEF}$ & Yes $(0.03)$ & Hard metal exposure $\times$ smoking habit \\
$\% \mathrm{MMF}^{\circ}$ & Yes $(0.03)$ & None \\
$\% \mathrm{~V}_{50}$ & Yes $(0.03)$ & Hard metal exposure $\times$ smoking habit \\
$\% \mathrm{~V}_{25}$ & Yes $(0.03)$ & None
\end{tabular}

*The model adopted was: ventilatory function index = exposure to hard metal + smoking habit + (exposure to hard metal $\times$ smoking habit). trophotometry as described previously. ${ }^{10}$ Air samples were obtained on two or more different working days; from these samples the arithmetic means were calculated and used as representative of the present daily exposure.

Indices for ventilatory function (forced vital capacity (FVC), forced expiratory volume in one second $\left(\mathrm{FEV}_{1}\right)$, forced expiratory volume in one second per cent $\left(\mathrm{FEV}_{1} \%\right)$, peak expiratory flow (PEF), mid-maximal flow (MMF), forced expiratory flow at $50 \%$ vital capacity $\left(\dot{\mathrm{V}}_{50}\right)$, and forced expiratory flow at $25 \%$ vital capacity $\dot{V}_{25}$ )) were derived from the flow volume curve from maximum forced expiratory manoeuvres, as described previously. ${ }^{10}$ Variables were expressed as percentages of predicted values $\left(\% \mathrm{FVC}, \% \mathrm{FEV}_{1}, \% \mathrm{FEV}_{1} \%\right.$, $\%$ PEF, $\% \mathrm{MMF}, \% \dot{\mathrm{V}}_{50}$, and $\% \dot{\mathrm{V}}_{25}$ ) by dividing the measured values by the predicted values derived from the predictive equations for each sex and multiplying by 100 . For calculation of $\%$ FVC, the equation developed by Baldwin $e t$ $a l^{19}$ was used. The equations by Berglund et $a l^{20}$ were used for calculation of $\% \mathrm{FEV}_{1}$ and $\% \mathrm{FEV}_{1} \%$. A preliminary study used the equation of Schmidt et $a l^{21}$ for calculation of $\% M M F$ and the equation of Cherniack and Raber $^{22}$ for $\% \mathrm{PEF}, \% \dot{\mathrm{V}}_{50}$, and $\% \dot{\mathrm{V}}_{25}$. These generated low values, with means of less than $80 \%$ even in the non-smoking and nonexposed workers. Therefore, the equations developed from Japanese men and women by Fujimoto et $a l^{23}$ were adopted for calculation of $\% \mathrm{PEF}, \% \mathrm{MMF}, \% \dot{\mathrm{V}}_{50}$, and $\% \dot{\mathrm{V}}_{25}$.

Differences in ventilatory indices between groups divided for various characteristics were examined by Student's $t$ test and by one way or two way analysis of variance (ANOVA) with Bonferroni's multiple comparison. Stepwise multilinear regression analysis of indices on various independent factors was conducted. Differences were considered to be significant at $P<0.05$. All of the statistical analyses were conducted with SAS procedures. $^{24}$

\section{Results}

CHARACTERISTICS OF SUBJECTS

Table 1 summarises the age, smoking habits, and occupational history of exposure to hard metal. The data on smoking for 10 men and one woman could not be obtained. Three men were exposed to steel dust alone. The 
Table 3 Two way ANOVA of indices of ventilatory function and exposure to hard metal and smoking in women

\begin{tabular}{|c|c|c|}
\hline Indices & $\begin{array}{l}\text { Significance } \\
\text { of } \text { model }^{\star}\left(R^{2}\right)\end{array}$ & $\begin{array}{l}\text { Significant } \\
\text { factor }\end{array}$ \\
\hline $\begin{array}{l}\text { \%FVC } \\
\% \mathrm{FEV}_{1} \\
\% \mathrm{FEV}_{1} \% \\
\% \mathrm{PEF} \\
\% \mathrm{MMF} \\
\% \mathrm{~V}_{50} \\
\% \mathrm{~V}_{25}\end{array}$ & $\begin{array}{l}\text { No } \\
\text { No } \\
\text { No } \\
\text { No } \\
\text { No } \\
\text { Yes }(0.11) \\
\text { No }\end{array}$ & Hard metal exposure \\
\hline
\end{tabular}

Footnote as for table 2 .

Figure 1 Ventilatory functions among the asthmatic and nonasthmatic currently exposed male workers. All of the indices except for $\% F V C$ were significantly lower in the asthmatic workers than in the non-asthmatic workers.

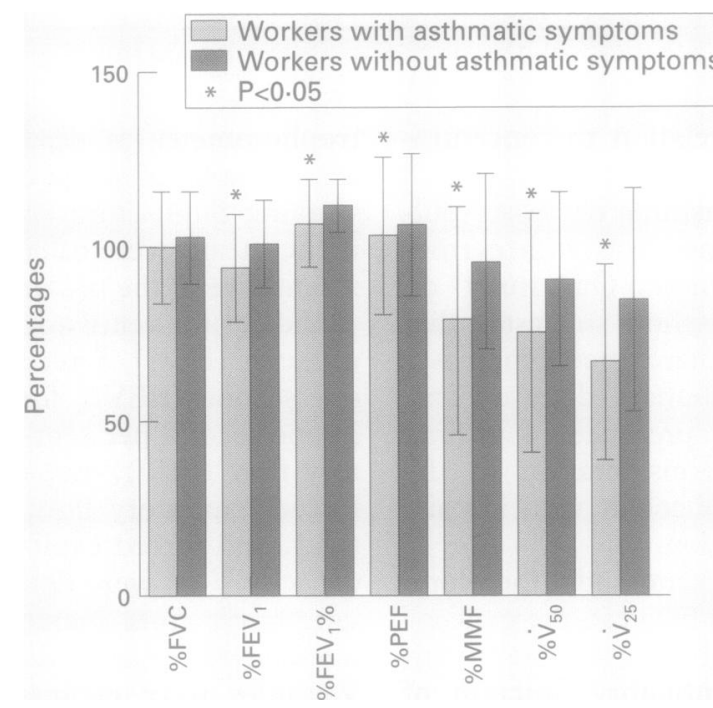

currently exposed workers were also stratified by whether the concentration of airborne cobalt was $\leqslant 50 \mu \mathrm{g} / \mathrm{m}^{3}, \quad 50-100 \mu \mathrm{g} / \mathrm{m}^{3}$, or $>100 \mu \mathrm{g} / \mathrm{m}^{3}$.

\section{VENTILATORY FUNCTION IN WORKERS BY EXPOSURE TO HARD METAL AND SIMOKING HABIT}

The ventilatory function in men was examined by two way ANOVA on exposure to hard metal (current, former, and no exposure), smoking habit (current, ex, and non-smoker), and interaction of the two factors. The model tested was:

indices of ventilatory function $=$ exposure to hard metal + smoking habit + (exposure to hard metal $\times$ smoking habit).

Table 2 shows that for men the models were significant for the variables $\% \mathrm{MMF}$ and $\% \dot{\mathrm{V}}_{25}$. Interaction of hard metal exposure and smoking had significantly decreased $\% \mathrm{FEV}_{1} \%$, $\%$ PEF, and $\% \dot{\mathrm{V}}_{50}$.

Table 3 shows the results from the women: only for $\% \dot{\mathrm{V}}_{50}$ was the model significant with

Table 4 Two way ANOVA of indices of ventilatory function on exposure to hard metal and smoking in men without asthmatic symptoms

\begin{tabular}{|c|c|c|}
\hline Indices & $\begin{array}{l}\text { Significance } \\
\text { of } \text { model }^{*}\left(R^{2}\right)\end{array}$ & $\begin{array}{l}\text { Significant } \\
\text { factor }\end{array}$ \\
\hline $\begin{array}{l}\text { \%FVC } \\
\% \mathrm{FEV}_{1} \\
\% \mathrm{FEV}_{1} \% \\
\% \mathrm{PEF}^{2} \\
\% \dot{M M F} \\
\% \mathrm{Y}_{50} \\
\% \mathrm{~V}_{25}\end{array}$ & $\begin{array}{l}\text { No } \\
\text { No } \\
\text { No } \\
\text { Yes }(0.03) \\
\text { No } \\
\text { Yes }(0.03) \\
\text { No }\end{array}$ & $\begin{array}{l}\text { Hard metal exposure } \times \text { smoking habit } \\
\text { Hard metal exposure } \times \text { smoking habit }\end{array}$ \\
\hline
\end{tabular}

Footnote as for table 2 . hard metal exposure alone being independently significant. Bonferroni's test clarified that the mean $\% \dot{\mathrm{V}}_{50}$ in the woman formerly exposed to hard metals ( $n=1)$ was significantly higher than that in the non-exposed or the currently exposed women. Interpretation of this was difficult because of small numbers.

\section{VENTILATORY FUNCTION IN WORKERS WITH} ASTHMATIC SYMPTOMS

Figure 1 shows that all indices of ventilatory function except for \%FVC were significantly lower in the currently exposed men with asthmatic symptoms than in those without. On the other hand, there was no difference for any index (data not shown) between the currently exposed $(\mathbf{n}=33)$ and non-exposed men $(n=$ 17) with asthmatic symptoms, indicating that the decrease of impairment of ventilatory function was similar in these two groups.

When men with asthmatic symptoms were excluded from the analysis two way ANOVA of indices of ventilatory function showed that the interaction of hard metal exposure and smoking still affected $\% \mathrm{PEF}$ and $\% \dot{\mathrm{V}}_{50}$ (table 4).

The same analysis for women did not show similar findings probably because of the few asthmatic women (data not shown).

\section{VENTILATORY FUNCTION IN CURRENTLY EXPOSED WORKERS WITH REFERENCE TO COBALT CONCENTRATION}

The currently exposed men were stratified into three groups by their workplace concentration of airborne cobalt: $\leqslant 50 \mu \mathrm{g} / \mathrm{m}^{3}$, between 50 and $100 \mu \mathrm{g} / \mathrm{mg}^{3}$, and $>100 \mu \mathrm{g} / \mathrm{m}^{3}$. The indices of ventilatory function for these subgroups were then compared with those in the non-exposed controls by $t$ test. There was a significantly lower $\% \dot{V}_{25}$ in those exposed to cobalt at a concentration of more than $100 \mu \mathrm{g} / \mathrm{m}^{3}$. Figure 2 shows that $\% \dot{\mathrm{V}}_{25}$ tended to decrease with increasing concentration of airborne cobalt, whereas \%FVC remained stable at all concentrations. One way ANOVA did not show a significant effect of cobalt exposures on any of the indices of ventilatory function (data not shown).

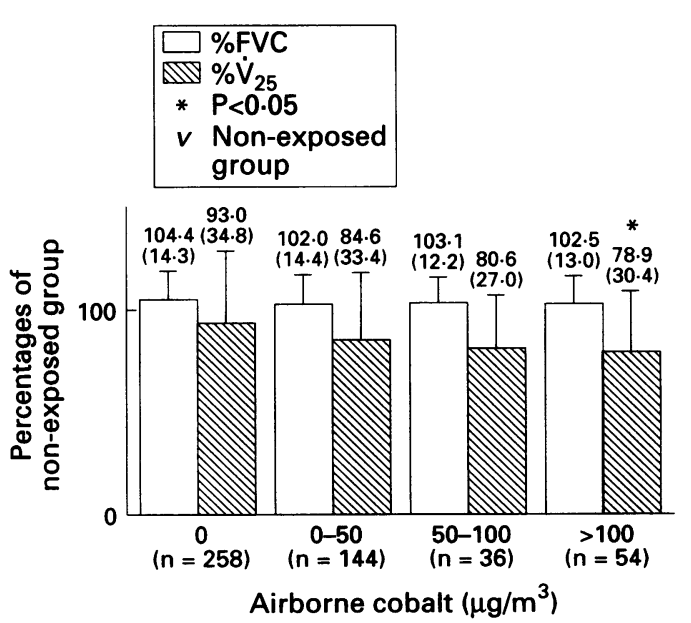

Figure 2 Dose dependent decrement in $\% V_{25}$ by airborne cobalt concentration (exposure level). 
Table 5 Multilinear regression analysis of indices of ventilatory function on independent variables in all subjects

\begin{tabular}{|c|c|c|c|}
\hline Indices and related factors & Estimate correlation & $R^{2}$ & Pvalue \\
\hline \multicolumn{4}{|l|}{ \%FVC: } \\
\hline Brinkman smoking index & -0.008 & 0.020 & 0.0002 \\
\hline Asthmatic symptoms & $-3 \cdot 736$ & 0.006 & 0.0350 \\
\hline \multicolumn{4}{|l|}{$\% \mathrm{FEV}_{1}$ : } \\
\hline Asthma & -6.916 & 0.021 & 0.0001 \\
\hline \multicolumn{4}{|l|}{$\% \mathrm{FEV}_{1} \%$ : } \\
\hline Asthmatic symptoms & $-4 \cdot 315$ & 0.020 & 0.0002 \\
\hline \multirow{2}{*}{\multicolumn{4}{|c|}{ \%PEF: }} \\
\hline & & & \\
\hline $\begin{array}{l}\text { Hard metal exposure } \\
\text { \%MMF: }\end{array}$ & 3.595 & 0.006 & 0.0407 \\
\hline Asthmatic symptoms & $-13 \cdot 200$ & 0.022 & 0.0001 \\
\hline \multicolumn{4}{|l|}{$\% \mathrm{~V}_{50}:$} \\
\hline Asthmatic symptoms & & 0.025 & 0.0001 \\
\hline $\begin{array}{l}\% V_{25}: \\
\text { Brinkman smoking index }\end{array}$ & -0.014 & 0.018 & 0.0003 \\
\hline Asthmatic symptoms & $-11 \cdot 769$ & 0.012 & 0.003 \\
\hline Hard metal exposure & $-5 \cdot 088$ & 0.006 & 0.045 \\
\hline
\end{tabular}

Table 6 Results of multilinear regression analysis of indices of ventilatory function among the non-exposed and the currently exposed groups and variables including both cobalt concentration and duration of exposure

\begin{tabular}{lcll}
\hline Indices and independent variables & Estimate correlation & $R^{2}$ & $P$ value \\
\hline \%FVC: & & & \\
Brinkman smoking index & -0.010 & 0.031 & 0.0001 \\
Sex & 4.212 & 0.008 & 0.023 \\
Duration of exposure & -0.217 & 0.008 & 0.023 \\
\%FEV & & \\
Asthmatic symptoms & -5.390 & 0.013 & 0.005 \\
\%FEV, & & & \\
Brinkman smoking index & 0.0047 & 0.024 & 0.0001 \\
Asthmatic symptoms & -3.175 & 0.012 & 0.008 \\
\%PEF: & & & \\
None & & & \\
\%MMF: & -9.850 & 0.014 & 0.004 \\
Asthmatic symptoms & -0.363 & 0.009 & 0.019 \\
Puration of exposure & & 0.017 & 0.002 \\
\% & -11.134 & 0.027 & 0.0001 \\
Asthmatic symptoms & -0.768 & 0.010 & 0.011 \\
\% & -0.011 & 0.044 & \\
Duration of exposure & -9.080 & & \\
Brinkman smoking index & & & \\
Asthmatic symptoms & & & \\
\hline
\end{tabular}

In the currently exposed women, the $\% \dot{\mathrm{V}}_{50}$ of those exposed to cobalt at concentrations of $50-100 \mu \mathrm{g} / \mathrm{m}^{3}$ was significantly lower than that in the non-exposed controls ( $t$ test). No indices were affected by the cobalt concentrations in one way ANOVA.

\section{MULTILINEAR REGRESSION ANALYSIS OF} INDICES OF VENTILATORY FUNCTION IN ALL HARD METAL WORKERS

The above univariate analyses and ANOVA showed that some indices of ventilatory func-

Table 7 Results of multilinear regression analysis on indices of ventilatory function in the non-exposed and the currently exposed groups and variables including cumulative dose as an exposure indicator

\begin{tabular}{lcll}
\hline Indices and independent variables & Estimate correlation & $R^{2}$ & Pvalue \\
\hline \%FVC: & & & \\
Brinkman smoking index & -0.010 & 0.031 & 0.0001 \\
Sex & 3.442 & 0.008 & 0.023 \\
\%FEV & & & \\
Asthmatic symptoms & -5.390 & 0.013 & 0.005 \\
\%FEV $\%$ : & 0.0047 & 0.024 & 0.0001 \\
Brinkman smoking index & -3.175 & 0.012 & 0.008 \\
Asthmatic symptoms & & & \\
\%PEF: & & & \\
None & -10.360 & 0.014 & 0.004 \\
\%MF: & -0.008 & 0.008 & 0.030 \\
Asthmatic symptoms & & 0.017 & 0.002 \\
Brinkman smoking index & -11.293 & 0.017 & 0.002 \\
\% & & 0.008 & \\
Asthmatic symptoms & -0.014 & & \\
\% & -10.159 & & \\
Brinkman smoking index & & & \\
Asthmatic symptoms & & & \\
\hline
\end{tabular}

tion were clearly related to smoking, asthmatic symptoms, and exposure to hard metal in both men and women. Therefore, to elucidate the independent effects of these factors on indices of ventilatory function, we conducted multilinear regression analysis on these indices in all subjects. For analysis, exposure to hard metal was dichotomised into current or former exposure (1) and no exposure (0): the asthmatic symptoms were dichotomised into presence of (1) and absence (0). The Brinkman smoking index was used as an independent variable representative of smoking habit which quantitatively reflects consumption of tobacco not only in current smokers but also in exsmokers. Sex $(\operatorname{men}=1$, women $=0)$ was also included in the independent variables.

Table 5 shows that asthmatic symptoms and smoking significantly and independently decreased all of the variables except $\% \mathrm{FEV}_{1}$. Exposure to hard metal significantly decreased $\% \dot{\mathrm{V}}_{25}$. The effect of sex was not significant.

\section{MULTILINEAR REGRESSION ANALYSIS OF} INDICES OF VENTILATORY FUNCTION IN WORKERS CURRENTLY EXPOSED AND NOT EXPOSED TO HARD METAL

The associations between independent variables and indices of ventilatory function were examined in the currently exposed workers and the non-exposed workers with stepwise multilinear analysis. The independent factors included sex, Brinkman smoking index, asthmatic symptoms, and indicators for hard metal exposure. As measures of hard metal exposure, concentrations of airborne cobalt $\left(\mu \mathrm{g} / \mathrm{m}^{3}\right)$, duration of exposure (years), and cumulative dose (multiplication of cobalt concentration by duration) were considered to be independent variables. As the cumulative exposure variable may confound duration of exposure, two analyses were performed. Firstly, the concentration and the duration were chosen as independent variables. Secondly, the cumulative dose alone was chosen as an independent variable for the exposure.

Table 6 shows that from the first regression analysis asthma and smoking had significantly decreased all of the indices except \%PEF. Also, the duration of exposure had a significantly decreasing effect on \%FVC, \%MMF, and $\% \dot{V}_{25}$. The cobalt concentration did not have a significant and independent effect on any indices. The increasing effect of being male was found only on \%FVC.

Table 7 shows the results from the second analysis. Although asthmatic symptoms and smoking had significantly decreasing effects on all indices except \%PEF, cumulative dose was not significant for any.

\section{Discussion}

The results of the present study differ from those in our previous report ${ }^{10}$ for ventilatory impairment related to exposure to hard metal. The association of decrease in $\mathrm{FEV}_{1} \%$ of the 47 shaping workers with hard metal exposure found previously was not confirmed in the present study. Two way ANOVA in the current 
study showed that a decrease in $\% \mathrm{FEV}_{1}$ was associated with interaction of exposure to hard metal and smoking. Moreover, a decrease in $\% \mathrm{FEV}_{1}$ was shown in the multiple linear regression analysis to be associated only with smoking and asthmatic symptoms. This difference might be partly related to the differences in methods of statistical analysis between the two studies.

Another explanation for the discrepancy may be a difference in the degree of pulmonary disease. The subjects of the previous study (1984) were 47 workers including three asthmatic people with moderate to severe ventilatory impairment due to asthma, whereas the present study (1987) included workers with asthmatic symptoms who may not have had as heavily impaired function as those in the previous study.

Also, there may have been a difference in duration of exposure or in the earlier dose to which the subjects of the two studies were exposed. The subjects of the previous study had been exposed to a mean cobalt concentration of $120 \mu \mathrm{g} / \mathrm{m}^{3}$ for the mean duration of 10 years before the study, although exact data on exposures to cobalt in the past could not be collected for both studies. Thus, there remains a possibility that notably heavy and prolonged exposure to cobalt results in decreased $\mathrm{FEV}_{1} \%$ especially associated with asthma and heavy smoking.

The exposed workers with asthmatic symptoms were found to have greater impairment of ventilatory function than the exposed workers without asthmatic symptoms, and the severity of deterioration of ventilatory function was not as pronounced as that in the nonexposed controls with asthmatic symptoms. However, we found that the onset of asthma may speed up in association with exposure to hard metal, especially with cobalt concentrations of less than $50 \mu \mathrm{g} / \mathrm{m}^{3}{ }^{25}$ Therefore, the inclusion of asthmatic workers has a notable effect on the measured impairment of ventilatory function. Furthermore, when the workers with asthmatic symptoms were excluded from analysis of the currently exposed workers, this group still had significantly lower ventilatory function than the non-asthmatic controls.

The correlation $\left(R^{2}\right)$ for each variable was small, which suggests that other independent factors such as working conditions, environmental pollution, and nutrition need to be explored in future studies. Irrespective of this, the present study leads to a hypothesis: that decreases of $M M F, \dot{V}_{50}$, and $\dot{V}_{25}$ in the workers, including those formerly exposed, are related to hard metal exposure. As shown from the multivariate analyses and partly from the ANOVA, hard metal exposure may cause persistent small airway disease with increasing duration of exposure. Except for people with asthmatic symptoms, workers currently exposed to hard metals did not seem to develop obstruction of the large bronchi as reflected by $\mathrm{FEV}_{1}$ or $\mathrm{FEV}_{1} \%$. The multilinear regression analysis of \%FVC also showed its positive association with the period of hard metal exposure, which may indicate progress of restrictive ventilatory impairment possibly compatible with pulmonary fibrosis.

A definite relation between concentration of airborne cobalt and the size of decrease in indices of ventilatory function was not confirmed by the multiple regression analysis for currently exposed workers. This evidence should be taken into consideration to establish and amend the standard limit for cobalt.

Our findings are partly consistent with the Swedish report by Alexandersson and Swensson, ${ }^{7}$ that decreases in $\mathrm{FEV}_{1}, \mathrm{FEV}_{1} \%$, and MMF were associated with exposure to cobalt at a mean concentration of $60 \mu \mathrm{g} / \mathrm{m}^{3}$. In that study the flow-volume curve which produces $\dot{\mathrm{V}}_{50}$ and $\dot{\mathrm{V}}_{25}$ was not measured. Again, it should be pointed out that the discrepancy between the studies may be the result of the ventilatory function tests being dependent upon the prevalences of asthma in the subjects.

On the other hand, in the study by MeyerBisch et al, ${ }^{9}$ at French hard metal plants, FVC, $\mathrm{FEV}_{1}$, or MMF did not show any significant relation with exposure to hard metal after controlling for age. Sprince $e t a f^{\beta}$ showed that with the same linear regression model as used by us, FVC and FEV 1 in hard metal workers in the United States were not correlated with exposure dose or duration. In neither of these studies did the flow volume curve follow the forced maximum manoeuvre used. In the American study, wheeze was not prevalent among the hard metal workers, whereas the French study showed a correlation between prevalence of work related wheeze and cobalt concentration. In the French study, unlike ours, no distinction was made between workers with wheeze (about $17 \%$ in the exposed subjects) and those without in the analysis of ventilatory function. These methodological discrepancies may have led to differences from our results.

The pulmonary function of Belgian employees at a cobalt refinery plant, ${ }^{12}$ a diamondcobalt saw production plant,,$^{13}$ and diamond polishing workshops ${ }^{14}$ have also been studied. Swennen et $a l^{12}$ found a positive association between decrease in $\mathrm{FEV}_{1} \%$ and cobalt concentrations in biological samples (urine, blood) collected at the largest cobalt refinery in the world. All of the indices of ventilatory function ( $\% \mathrm{FVC}, \% \mathrm{FEV}_{1}, \% \mathrm{FEV}_{1} \%, \% \mathrm{PEF}$, $\% \mathrm{MMF}, \% \dot{\mathrm{V}}_{50}, \% \dot{\mathrm{V}}_{25}$ ) examined in a study by Gennart and Lauwerys ${ }^{13}$ conducted at a diamond-cobalt saw production plant showed a significant decrease in association with the duration of exposure, which is consistent with our results. Nemery et $a l^{14}$ pointed out the presence of impairment of ventilatory function ( $\% \mathrm{FVC}$ and $\% \mathrm{FEV}_{1}$ ) among polishers exposed to cobalt even at concentrations of less than $50 \mu \mathrm{g} / \mathrm{m}^{3}$ and noted its significant relation to the cobalt concentration in urine in a linear regression model. At a Danish porcelain factory, Raffn $e t a^{26}$ found a decrease of $\dot{\mathrm{V}}_{25}$ in workers exposed to cobalt in blue dye compared with controls. All of these reports suggest that occupational exposure to cobalt has an adverse effect on ventilatory function. 
Smoking is a well known confounding factor for occupational respiratory diseases, as we have found. Smoking should be avoided by workers exposed to hard metal, although the exposure alone also disturbs the bronchi. Furthermore, the impairment of ventilatory function can be enhanced by asthma attacks, which are related to exposure to hard metal.

The functional impairment in the small airways found in the current study needs to be followed up, to find its possible association with chronic bronchial obstruction and respiratory failure. Thereafter, results from the present cross sectional study should be extended. Asthmatic workers with impairment in the large bronchi should also be followed up.

1 Coates EO, Watson JHL. Diffuse interstitial lung disease in tungsten carbide workers. Ann Intern Med 1971;75: tungsten

2 Davison AG, Haslam PI, Corrin B, Coutts II, Dewar A, Riding WD, et al. Interstitial lung disease and asthma in hard-metal workers: bronchoalveolar lavage, ultrastructural, and analytical findings and results of bronchial provocation tests. Thorax 1983;38:119-28.

3 Kusaka Y, Yokoyama K, Sera Y, Yamamoto S, Sone S, Kyono $\mathrm{H}$, et al. Respiratory diseases in hard metal workers: an occupational hygiene study in a factory. $\mathrm{Br} \mathcal{F}$ Ind Med 1986;43:474-85.

4 Shirakawa T, Kusaka Y, Fujimura N, Goto S, Kato M, Heki S, Morimoto K. Occupational asthma from cobalt sensitivity in workers exposed to hard metal dust. Chest sensitivity in work

5 Schepers GWH. The biological action of particulate cobalt metal, tantalum oxide, cobalt oxide, tungsten metal, tungsten carbide and carbon, tungsten carbide and cobalt. Arch Ind Health 1955;12:121-46.

6 Kerfoot EJ, Frederick WG, Domeier E. Cobalt metal inhalation studies on miniature swine. Am Ind Hyg Assoc 7 1975;36:17-25.

7 Alexandersson R, Swensson A. Studies on the pulmonary reaction of workers exposed to cobalt in the tungsten carbide industry. Arh Hig Rada Toksikol 1979;30(suppl): 355-61.

8 Sprince NL, Oliver C, Eisen EA, Greene RE, Chamberlin RI. Cobalt exposure and lung disease in tungsten carbide production. A cross-sectional study of current workers. Am Rev Respir Dis 1988;138:1220-6.

9 Meyer-Bisch C, Pham QT, Mur J-M, Massin N, Moulin J$\mathrm{J}$, Teculescu D, et al. Respiratory hazards in hard metal workers: a cross sectional study. $B r$ f Ind Med 1989; 46:302-9.

10 Kusaka Y, Ichikawa Y, Shirakawa T, Goto S. Effect of hard metal dust on ventilatory function. $\mathrm{Br} F$ Ind Med 1986; 43:486-9.

11 Roto P. Asthma, symptoms of chronic bronchitis and ventilatory capacity among cobalt and zinc production workers. Scand $\mathcal{F}$ Work Environ Health 1980;6(suppl 1):1-49.

12 Swennen B, Buchet J-P, Stanescu D, Lison D, Lauwerys R. Epidemiological survey of workers exposed to cobalt oxides, cobalt salts, and cobalt metal. Br F Ind Med 1993; 50:835-42.

13 Gennart JPh, Lauwerys $\mathrm{R}$. Ventilatory function of workers exposed to cobalt and diamond containing dust. Int Arch Occup Environ Health 1990;62:333-6.

14 Nemery B, Casier P, Roosels D, Lahaye D, Demedts $M$. Survey of cobalt exposure and respiratory health in diamond polishers. Am Rev Respir Dis 1992;145:610-6.

15 International Labour Office. Occupational exposure limits for airborne toxic substances. 3rd ed. Geneva: ILO, 1991:108.

16 Kusaka Y, Yokoyama K, Sera Y, Shirakawa T, Goto S, Morimoto K. Evaluation of the self-administered respiratory questionnaire recommended by the Japanese Labour Ministry based on the standardized interviewer-administered BMRC Questionnaire. Fpn $\mathcal{F}$ Ind Health 1989;31: 415-20.

17 Medical Research Council Committee on the Aetiology of Chronic Bronchitis. Standardized questionnaire on respiratory symptoms. BMๆ 1960;2:1665.

18 Brinkman GL, Coates EO. The effect of bronchitis, smoking, and occupation on ventilation. Am Rev Respir Dis 1963;87:684-93.

19 Baldwin EDEF, Cournand A, Richard DW. Pulmonary insufficiency. I. Physiological classification, clinical methods of analysis, standard values in normal subjects. Medicine 1948;27:243-78.

20 Berglund E, Birath G, Bjure J, Grimby G, Kjellmer I, Sandgvist L, Söderholm B. Spirometric studies in normal subjects. I. Forced expirograms in subjects between 7 and 70 years of age. Acta Med Scand 1963;173:185-92.

21 Schmidt CDu, Dickman ML, Gardner RM, Brough GK Spirometric standards for healthy elderly men and Spirometric standards for healthy elderly

22 Cherniack RM, Raber MB. Normal standards for ventilatory function using an automated wedge spirometer. $\mathrm{Am}$ Rev Respir Dis 1972;106:38-46.

23 Fujimoto J, Hata $M$, Kondo $M$, Hirota $M$, Shima $K$. Standard values and prediction equations for respiratory function measurements. (II) Flow-volume curve measurements in healthy Japanese. Respiration and Circulation 1986;34:673-9.

24 SAS Institute. SAS/STAT User's guide, ed 6.08. Cary:SAS Institute, 1993.

25 Kusaka Y, Iki M, Kumagai S, Goto S. Epidemiological study of hard metal asthma. Occup Environ Med 1996;53: 188-193.

26 Raffn E, Mikkelsen S, Altman DG, Christensen JM, Groth $S$. Health effects due to occupational exposure to cobalt blue dye among plate painters in a porcelain factory in Denmark. Scand $尹$ Work Environ Health 1988;14:378-84.

\section{Correspondence and editorials}

Occupational and Environmental Medicine welcomes correspondence relating to any of the material appearing in the journal. Results from preliminary or small scale studies may also be published in the correspondence column if this seems appropriate. Letters should be not more than 500 words in length and contain a minimum of references. Tables and figures should be kept to an absolute minimum. Letters are accepted on the understanding that they may be subject to editorial revision and shortening.

The journal also publishes editorials which are normally specially commissioned. The Editor welcomes suggestions regarding suitable topics; those wishing to submit an editorial, however, should do so only after discussion with the Editor. 